\title{
Outsourcing: Current and Future Trends
}

\author{
Andrew Kakabadse - Nada Kakabadse
}

\begin{abstract}
Executive Summary
Highlighted are two reasons for outsourcing: cost and focus on the core competencies of the enterprise. Surveying U.S., U.K., and Continental Europe companies concerning current and future outsourcing trends positions outsourcing as a prominent strategic lever. Achieving "best-of-breed" practice is predicted to occur through new technology. Also, human resources and IT outsourcing will become more prominent. The results strongly indicate that partnership alliances and performance-driven contracts will become as important as the current preferred, trusted supplier relationship. Keiretsulike, horizontal linkages will be required to realize scale and competency advantages from future outsourcing arrangements. (C) 2005 Wiley Periodicals, Inc.
\end{abstract}

\section{INTRODUCTION}

utsourcing, dating back to the Romans, notably with the sourcing out of tax collection, regained popularity in eighteenth-century England and has been in continuous use in a variety of forms ever since (Duffy, 2001). Outsourcing gained greater impetus in the 1970s, when large and diverse corporations were considered to be underperforming, a trend that became even more pronounced in the early 1980s with the onset of global recession (Kakabadse \& Kakabadse, 2000). In fact, the 1980s witnessed a change of direction in business strategy thinkingnamely, focusing on fewer activities (Peters \& Waterman, 1982). As a result, corporate managers reevaluated the concept that the organization needed to be vertically integrated and self-sufficient (Mullin, 1996). Thus, corporations divested "peripheral or supplementary" businesses in order to focus upon their "core" business and, in turn, become "de-integrated" by increasingly outsourcing their requirements for components and business services (Grant, 1995, p. 381). By the 1990s, the agenda was set, with the growing belief that quick wins could be

Andrew Kakabadse is a professor of international management development at Cranfield University, UK [a.p.kakabadse@cranfield.ac.uk].

Nada Kakabadse is a professor in management and business research at the University College, Northampton, UK. 
achieved by pursuing "core" strategies (Prahalad \& Hamel, 1990). Many firms began reengineering, in effect embarking on a search for new ways of organizing the various elements of work. Such "new beginnings" promoted a rethink and radical redesign of business processes in order to achieve dramatic improvements in critical areas of performance such as cost, quality, service, and speed (Gamble, 1995).

Many firms Further, with the proliferation and rapid pace of change of informabegan reengition technology (IT), IT became the most controversial part of the neering, in effect embarking on a search for new ways of organizing the various elements of "outsourcing revolution" as numerous "mega-deals" worth over $£ 1$ billion produced below-expected results (Kakabadse \& Kakabadse, 2002a). Whether IT is a support service or more critical to the competitive position of many firms and should definitely be retained inhouse dominated the outsourcing debate among academics and practitioners alike (Koudsi, 2001).

work.

Some argue that IT is an activity that can inherently lead a firm toward a dependency on its suppliers and therefore should only be outsourced in parts, while others argue for fully realizing outsourcing benefits (Carey, 1995).

In order to capture the nature of the trends in outsourcing, attention is given in this article to examining the reasons for outsourcing, the functions and activities outsourced, the nature of the sourcing arrangements, and the impact of outsourcing on employees. Further, the results of an extensive, international survey exploring current and likely future trends in outsourcing are reported. It is concluded that the enhancement of core competencies will continue through greater attention to the effective management of costs and through greater efficient application of transactional skills in the day-to-day management of a variety of configurational arrangements. It is also forecast that partnership arrangements will become more popular leading to "Keiretsu-like interactions" between purchasers and suppliers in order to effectively realize the benefits to be gained from outsourcing.

\section{EMERGING TRENDS FROM THE LITERATURE}

The more it became conventional wisdom that core activities should stay in-house, while noncore activities should be outsourced (Mullin 1996; Prahalad \& Hamel, 1990), the greater the attention that was given to identifying what is a "core competency" (Insinga \& Werle, 2000). May (1998) suggests that the identification of core competencies requires assessment of the contribution of every activity to be undertaken in an organization to decide whether: 
- it has a direct effect on satisfying customers' needs;

- outsourcing would achieve comparable quality more cheaply;

- re-allocation of resources to other activities would earn a superior return; and

- other benefits might arise from outsourcing, such as:

- lower inventory cost,

- reduced management time, and

- improved production flow.

...outsourcing

has become big

business, and its

effective man-

agement is criti-

cal to the future

success of an

organization. outsourcing deals in the year 2000 reveals contract expenditures of almost U.S. $\$ 56$ billion. Larger contract sizes range from U.S.\$58 million to U.S.\$7.5 billion, with most deals falling in between the U.S.\$100 and U.S.\$249 million range (IDC, 2000). Contracts of such enormity introduce their own challenges, as according to a recent study, more than half of all outsourcing customers are dissatisfied and report having renegotiated a contract, and in nearly one-quarter of the renegotiations, the suppliers lost that account (James, 2000).

However, the undisputed truism is that outsourcing has become big business, and its effective management is critical to the future success of an organization (Kakabadse \& Kakabadse, 2002a). As shown, the size of outsourcing contracts has reached astounding proportions, as witnessed by both Fiat's U.S.\$7 billion deal and NTL's U.S.\$2 billion deal with IBM's Global Services (Bain, 2000; Heikkila, 2000; McCure, 2001). Thus, in the following section of the article, we explore the trends in terms of reasons for outsourcing, what areas/activities have been outsourced, outsourcing arrangements, and outsourcing impact on employees.

\section{Sourcing Reasons}

Achieving economies of scale is highlighted as a critical reason for outsourcing (Table 1). Recently conducted research examining the outsourcing practices of numerous organizations concluded that Western companies outsource primarily to save on overheads through short-term cost savings (Klein, 1999). This finding has been echoed by other studies, which show that a prime driver for IT outsourcing is cost-effective access to specialized computing and systems development skills (Finlay \& King, 1999). 


\section{Table 1. Trends in Outsourcing: An Overview}

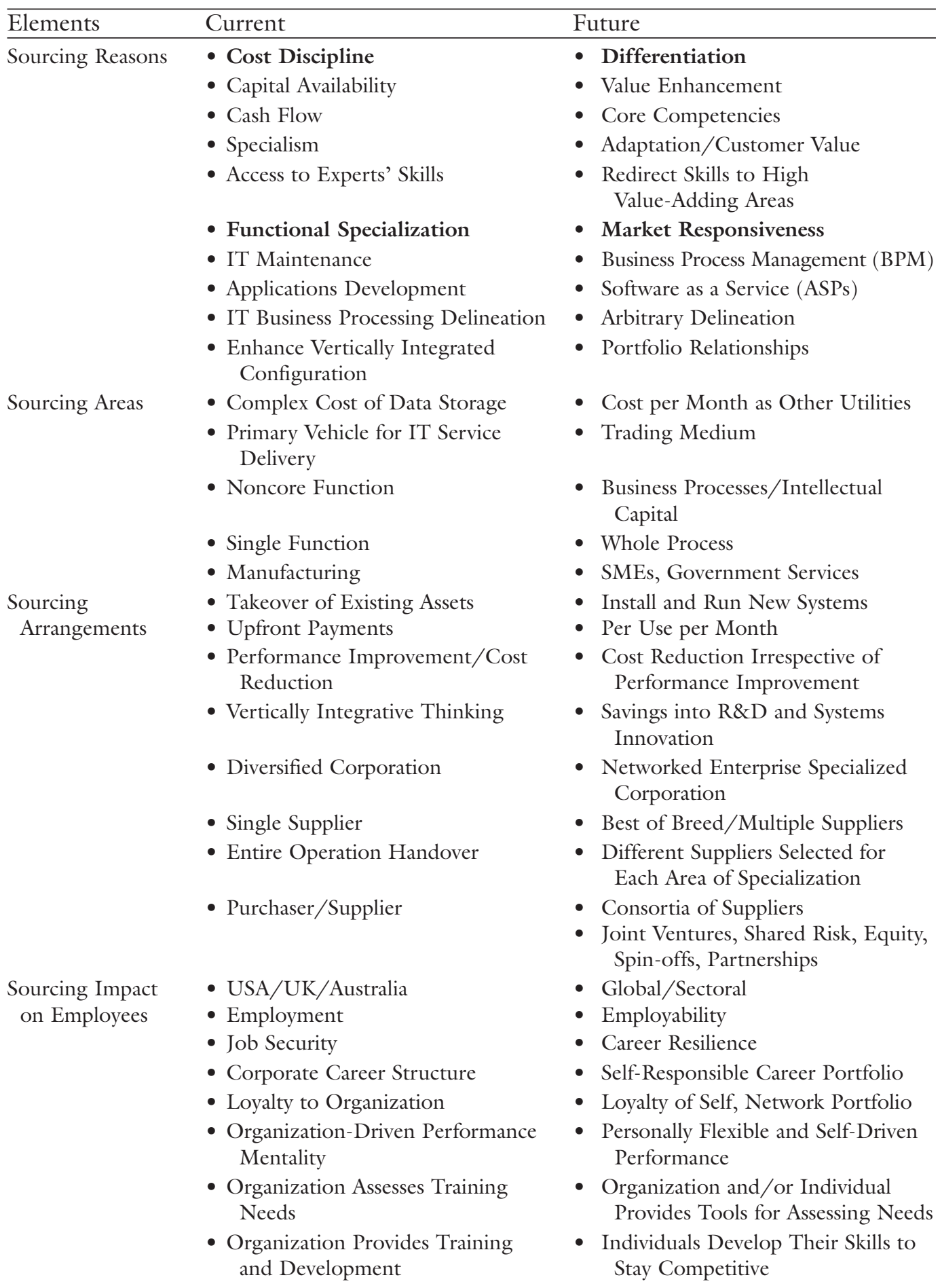

Adapted from Kakabadse and Kakabadse (2000). 
Equally emphasized is that global competition has not only compelled companies to apply greater discipline over costs but also over product-to-market time cycles, resulting in smaller product and services portfolios and a loosening of the vertical links in the production process (Quinn \& Hilmer, 1994). Consequently, corporations have divested activities that they regard as peripheral to their business and focused upon their "core" activities, which, for many, leads to increased specialization, while still pursuing other value-adding objectives (Willman, 1999). Such multiplicity has added a new dimension to outsourcing, that of attempting to manage numerous and, at times, ill-fitting sourcing strategies (Cunningham, 2001). A review of the literature emphasizes that now and into the future, determining what is core to the organization so that those processes and activities considered peripheral can be passed over to an external service provider will continue to be a prime consideration (Chalos \& Sung, 1998; Currie \& Willcocks, 1997).

...the trend

being captured

is a move

toward greater

business focus

through the

development of

business process

management

(BPM) skills.

While some consider core activities to be synonymous with core competencies, other writers consider that what is core and noncore is an academic debate (Kakabadse \& Kakabadse, 2000). The contrasting view put forward is that outsourcing decisions should be driven by the purpose of the sourcing contracts, the relationships between the purchaser and supplier, the leverage gained from outsourcing to determine greater competitive advantage and the effective management of contracts, which, in turn, lead to the development of a new cluster of competencies (DiRomualdo \& Gurbaxani, 1998). Hence, effectively managing outsourced relationships becomes a core competence itself (Alexander \& Young, 1996). Poor management of outsourced relationships reduces the opportunity for realizing competitive advantage as the poorly developed service purchaser/service provider relationship inhibits fully leveraging the suppliers' competencies (Costa, 2001).

An additional trend identified is from outsourcing elements of the organization, such as maintenance, data storage, or IT service delivery toward sourcing in or out more knowledge-based systems, such as customer response handling, procurement, and even the skills of managing critical processes (van Laarhoven, Berglund, \& Peters, 2000). In effect, the trend being captured is a move toward greater business focus through the development of business process management (BPM) skills (Hurley, 2001). On this basis, the delineation between what is critical or noncritical, or what is a part, a facility, and a component in contrast to a whole process, becomes arbitrary (Foremski, 1999). 


\section{SOURCING AREAS}

The area that has received substantial attention in the outsourcing literature has been IT (Hurley, 2001). The ever-greater emphasis on discipline over costs, the migration to flatter organizations, the requirement for greater flexibility, and rapid changes in technology

..e-commerce has been and is considered likely to continue defining trading in terms of "make, buy, process, sell" decisions. have promoted ever-greater IT outsourcing (Nairn, 1999). IT outsourcing has been encouraged by the technological advancement in data storage capability, which has dramatically increased in quality and significantly decreased in cost (Gartner Group, 1999). Thus, data storage services are being charged on a cost-per-megabyte-permonth basis, similar to payment for utilities as electricity and water, providing IT with more of a "commodity" status (Costa, 2001). Further, companies, in their pursuit of competitive advantage, have increased their reliance on external suppliers of information services. In fact, the International Data Corporation forecasts a global IT outsource market of more than $£ 151$ billion by 2003 , focusing on processing services, such as payroll, claims, and credit card processing (IDC, 2000).

In parallel, e-commerce has been and is considered likely to continue defining trading in terms of "make, buy, process, sell" decisions. Setting up a Web site for online sales can be expensive (Forrester Research, 1999). In-house expertise is required in server management, security, and related technical functions (Barthelemy, 2001). Further, such expertise is in short supply. Small and medium-sized enterprises (SMEs), unable to afford such resources on a full-time basis, are increasingly turning to external service providers to host their Web sites (Murray \& Kotabe, 1999). Even software suppliers themselves have entered into outsourcing arrangements with application service providers (ASPs) to supply and manage applications remotely, charging a flat fee per user (Forrester Research, 1999).

Partly because IT has a significant impact on the functioning of the organizations and partly because of the ever-changing views of what is core or noncore to the enterprise, the literature highlights the allembracing nature of outsourcing (Gupta, 2000). Under the umbrella of BPM, outsourcing has not only penetrated the SME and small business market but public services as well (Costa, 2001). The effect of deregulation, the creation of new agencies through quangos and the vigorous application of "best value" have been profound influences on the previously vertically integrated public-service organizations (Halachmi \& Montgomery, 2000). Governments in the 
United Kingdom, the United States, Canada, Australia, and New Zealand, in particular, have pursued best value with zeal in order to demonstrate continuous improvement in services and, as such, have altered the configurational profile of government organizations. The growth in horizontal linkages between public-service agencies and private-sector suppliers has been substantial. One consequence of government-driven outsourcing, however, has been the decline of business opportunities for small to medium-sized IT firms. Strongly influenced by the potential for cost savings through the ever-greater application of IT, greater economies of scale are purportedly achieved through outsourcing with large suppliers (Lavelle, Krumwiede, \& Sheu, 2000). In Australia, for example, organizations such as IBM and EDS are reported as the prime suppliers of outsourcing services (Costa, 2001). The opponents of best value and human rights activists fear that such developments are now placing the large providers in a position of almost acting as government itself, or at least, as unduly influencing government (Kakabadse \& Kakabadse, 2002a).

\section{SOURCING ARRANGEMENTS}

The scope of emerging arrangements between host and suppliers is extensive (Murray \& Kotabe, 1999). At one end are short-term contracts designated to encourage flexibility. At the other exists full ownership of and/or merger between purchaser and providers. Alternative arrangements lie in between, such as partial ownership, joint developments, retainers, other long-term contracts, relationships with trusted suppliers, single contracts, multiple vendor contracts, joint ventures, individual and joint venture spin-offs, consortia, and shared-service consortia (Domberger, 1998).

The emergence of partnership or alliance arrangements as alternatives to the more popular project-based contracts, which are usually shorter, single contracts with preferred, trusted suppliers, is considered to provide a closer level of interaction between client and provider. Most partnership arrangements, whether flexibly defined or more formal, involve shared risk and benefit (Miles \& Snow, 1997). The assumption is that any single vendor does not possess world-class capabilities in all areas of business and, hence, the need to embark on selective outsourcing with multiple vendors. Even such relationships vary, ranging from one vendor acting as prime contractor to all or most of the vendors enjoying equal status (Gupta, 2000). 
A further outcome of contract innovation has included joint ventures, cross equities, and franchises, typified by the Virgin organization, as their interests include retail, travel, soft drinks, music, financial services, and other business ventures (Nee, 1999). The Virgin practice has been to provide the brand name and marketing capability while the other joint venture partners provide specialist ser-

Practices that enhance information sharing and protect key competencies aid the management of strategic alliances. vices, production facilities, and capital. A further alternative arrangement is that of spin-offs, whereby an internal cost based activity is fully exposed to market forces (Chalos \& Sung, 1998). In effect, a cost center is turned into a separately managed profit center. A considerable number of examples exist of firms developing world-class competencies that are tangential to the parent's traditional line of business. General Motors's spin-off of EDS and Mercedes Daimler's IT-based service company of Debis are two such examples (Blumenstein, 1997; Cusumano \& Takeishi, 1991).

Even looser outsourcing arrangements are alliances, consortia, and shared-service agreements. Strategic alliances are seen by some as an "in vogue" arrangement, because of the capacity to bring together partners who hold differing and possibly conflicting objectives (Inkpen \& Beamish, 1997). Whatever the reasons for the alliance, transparency between the partners is considered to be vital. Practices that enhance information sharing and protect key competencies aid the management of strategic alliances (Hurley, 2001).

A further form of strategic alliance is consortia-based outsourcing, or sourced-service consortia. NV Philips, the global Dutch electronics company, set up a joint venture, BSO-Origin, involving equity shares and seats on the management board, with BSO Beheer, the Dutch software enterprise, in order to outsource its applications development function (Klein, 1999). Later, the parent, Philips, and BSOOrigin worked together to deliver services in the open market and, as a consequence, gained the cooperation of further software service providers, ultimately emerging as a sourced-service consortia enterprise. Overall, whatever form of arrangement is in vogue, the reported trend is less toward the takeover of existing assets by the supplier to the installation and running of new or alternative systems with consequent changes in the structure of payment for services (Teresko, 1999). The shift is from upfront payments to "pay as you go," or more properly, payments per month. Such emerging arrangements are considered as combining cost reduction with performance improvement and R\&D and systems innovation. The shift is from vertically integrative thinking to the networked enterprise that provides innovative, best-of-breed services (Currie \& Willcocks, 1997). 


\section{OUTSOURCING IMPACT OF EMPLOYEES}

The IT revolution and the ever-greater requirement by companies to differentiate themselves from competitors through a variety of means, including how to simultaneously address both cost and service-quality advantages, have dramatically affected the shape of jobs and promoted a redesign in the way work is structured (Richbell, 2001; Sparrow, 2000). Job-based flexibility has now become a norm. Large enterprises in the developed and emerging economies are increasingly adopting limited-term contracts, associate-like relationships, and home-based teleworking as standard contractual relationships with employees (Standen, Daniels, \& Lamond, 1999). However, the advantages are not all one-way, as the individual is also considered to benefit from the more flexible arrangements, allowing for greater disposable time. In the European Union in 1998, there were 1.1 million people, approximately $0.8 \%$ of the workforce, employed according to such arrangements, and by the year 2000 , this figure was estimated to stand at 4.4 million people, or $3.1 \%$ of the workforce (Tregaskis, 1999). Further, both private-sector and public-service enterprises are increasingly adopting part-time, temporary, casual, and fixed-term contractual arrangements as a means for securing both cost advantage and labor flexibility (Mishra, Spreitzer, \& Mishra, 1998; Shelgren, 2000). Such arrangements reflect a change of understanding in the relationship between employee and employer-namely, from job security in exchange for "loyalty" to one of performance for reward (Tyson \& York, 2000). The pay-for-performance and career-resilience perspectives capture the change of heart from reliance on the employer to provide developmental opportunities to the employee attending to his/her own training and career progress. An emerging perspective is that employees no longer respect or even desire a supportive social contract between themselves and their employer. In effect, maintaining employee commitment is "all but gone" (Kakabadse \& Kakabadse, 2000)!

Pursuing the trends identified in the reviewed literature, the following section presents the findings from a recent survey examining the reasons for outsourcing, the areas/activities that have been outsourced, outsourcing arrangements, and the impact of outsourcing on employees.

\section{THE SURVEY}

A survey of U.S., U.K., and continental European enterprises across a wide range of sectors, such as financial services (e.g., banks, insur-

Thunderbird International Business Review • March-April 2005
An emerging perspective is that employees no longer respect or even desire a supportive social contract between themselves and their employer. 
ance organizations, investment funds), IT/telecommunications, supply chain, logistics, and pharmaceuticals/chemicals, was undertaken. The study was pursued in two stages. Semistructured, face-to-face interviews with $50 \mathrm{CEOs,} \mathrm{general} \mathrm{managers,} \mathrm{directors,} \mathrm{and} \mathrm{managing}$ directors (MDs) were conducted in order to identify key trends and current critical issues in outsourcing. The learning from these inter-

In terms of current practice, aiming to achieve best practice while attempting to enforce appropriate cost disciplines and controls score closely. views was utilized in drafting a questionnaire examining current and future outsourcing trends. The validated instrument was distributed among large and medium-size enterprises. Seven hundred and fortyseven organizations participated in the survey. The greater majority of the respondents held senior manager positions, either as senior general managers or as executive directors and nonexecutive board members (Kakabadse \& Kakabadse, 2002a). Although the pattern of responses varied across the sample, no statistically significant trends across sectors or across functional responsibilities emerged. Thus, the reported results capture the critical significant trends to have emerged across the whole sample population.

\section{SURVEY RESULTS}

For us, outsourcing is the process whereby noncompetitive functions and activities are combined with the same functions of other firms to gain economies of scale. To us, outsourcing brings benefit by removing noncompetitive activities from our organization and pooling them with other organizations to gain economies of scale that would never be achievable if the functions were maintained internally.

$$
\text { (Senior Executive, Financial Sector) }
$$

\section{Sourcing Reasons}

There is an economic case for outsourcing. We realize economies of scale. We also put market forces into play, which require organizations to make a fundamental reappraisal of their activities. For the outsourced activities, the organization knows what they are getting for their money and we can monitor performance against cost. For the service provider, that is their core business.

(General Manager, Financial Services)

Distinct clusters of reasons emerge for pursuing outsourcing now and into the future (Figure 1). In terms of current practice, aiming to achieve best practice while attempting to enforce appropriate cost disciplines and controls score closely. Further, but not quite as highly rated, are service quality closely ranked with focusing on better leveraging the core competencies of the organization. A third cluster of reasons for undertaking outsourcing is identified and includes issues 
Figure 1. Outsourcing Purpose

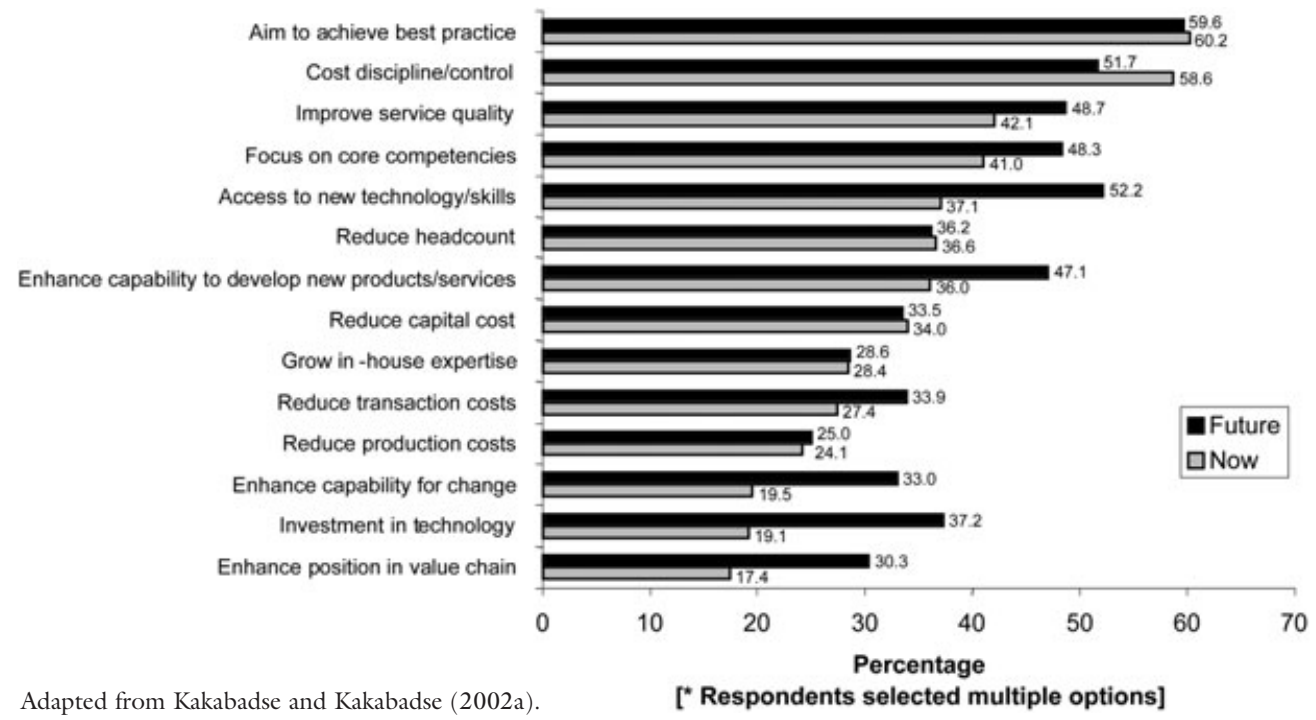

such as gaining access to new technology and skills that were not available in the organization, reducing headcount, enhancing the organization's capability to develop new products and services, and reducing capital costs.

In terms of predicted future reasons for outsourcing, achieving best practice is identified as critical. In support of striving for best practice, the adoption of new technology through best-in-class suppliers while maintaining strict control over costs emerges as a close second.

From there on in, a number of different reasons closely cluster, emphasizing the need for further enhancement of capability within the organization. Improvements in service quality, a continued emphasis on the core competencies of the organization, and the enhancing of the firm's product/service portfolio are the areas seen as important for improving the organization's capability to differentiate and gain advantage. As is the case currently, monitoring and enhancing cost disciplines through various means is likely to continue into the future. The one difference to emerge between current and future reasons for outsourcing is that greater priority is likely to be given to the sourcing of new technology and related skills. No significant response was received concerning the spinning off of the 
noncore parts of their organization in order to improve the level of profitability of the host organization. The survey results highlight that now and into the future as much attention will be given to reducing costs as to strategically focusing the organization on gaining greater competitive advantage. The critical difference is the degree of utilization of technology.

\section{SOURCING AREAS}

We have outsourced all of our noncore activities. There are only a few sacrosanct activities that we do not consider for outsourcing, such as strategy planning. But then again, that is today, tomorrow we may start debating it.

(IT Director, Utilities)

In contrast to the attention given to IT outsourcing in the literature, basic services (canteen facilities, office services), human resources (HR) activities, and IT-related activities and processes, in that order, are the areas currently given greatest attention in terms of outsourcing (Figure 2).

\section{Figure 2. Business Processes/Functions}

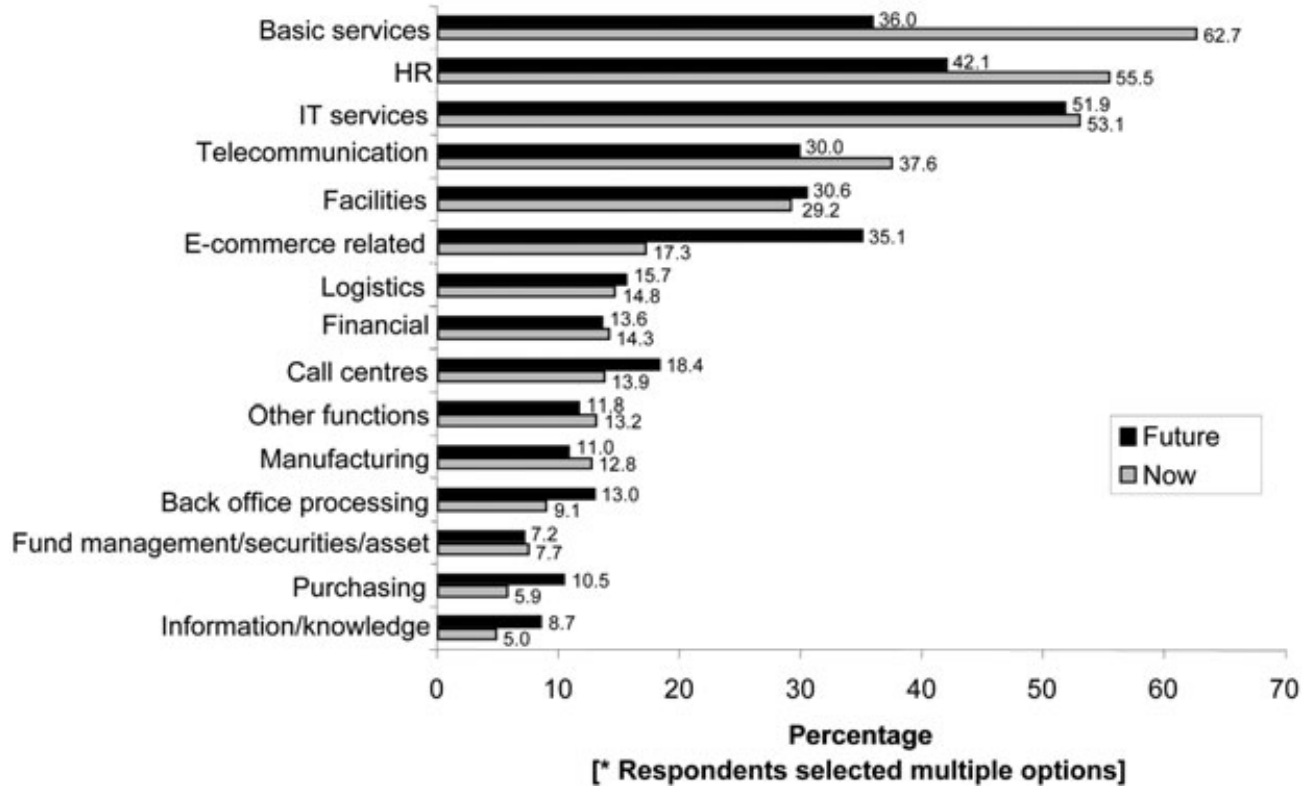

Adapted from Kakabadse and Kakabadse (2002a). 
The reverse is predicted for the future, whereby IT services and HR processes and activities, in that order, are likely to receive the greatest attention. The survey respondents indicate that IT-based activities and services will continue to be a major focus of outsourcing due to ever more rapid advances in technology. As additional IT-based innovation becomes commercially available, IT outsourcing will continue. In terms of $\mathrm{HR}$, the increased use of Internet-based technologynamely, information publishing, database enquiry, employee-based HR transactions, and HR workflow-makes these activities prime candidates for outreaching. How much and what other activities are outsourced within the HR function depends on each senior executive's view of the values of elements of the HR function. However, once the objectives of HR outsourcing have been achieved, human resources systems and processes will no longer be a prime target for outsourcing. Hence, high levels of HR outsourcing activity are expected to continue, but for a limited period.

Additional areas for future outsourcing are e-commerce-related processes/activities, facilities management, and telecommunication services. The future outsourcing of other functions, such as logistics, accounting services, purchasing, and back office processing, fall lower on the list of priorities. An emerging difference between current patterns and future likely outsourcing practice is in the area of e-commerce, whereby the outsourcing of such activities and processes is predicted to substantially increase.

The study reveals that senior executives consider that virtually no activities are protected from outsourcing, even within public-sector organizations. A particular case is that of defense, where private companies were providing communication services to U.K. field troops during the Kosovo war. The U.K. Ministry of Defense now plans to outsource their entire training, logistics, and supply-chain operations to private service providers, a far-reaching encroachment into what was traditionally considered the state's preserve. A further example concerning the future is the planned management of the Armed Forces secret files that cover Northern Ireland and the Gulf War being turned over to the private sector ("Privatising War," 2003).

\section{ARRANGEMENTS}

Today, we have strategic partners relations (mostly in the Indian Sub-Continent) who provide our application development and IT 
support. This strategy has brought considerable and growing economic benefit to the firm.

(Finance Director, Financial Services)

The two current preferred sourcing arrangements are single contracts, in particular with trusted suppliers with whom there is already an established relationship (Figure 3). At present, "less traditional" contractual relationships, such as strategic alliances, contracts with multiple suppliers offering an integrated high-quality service, flexible pricing contracts, and various forms of partnerships, are identified as less popular than the preferred supplier/single-contract mode of operating. Similarly, into the future, the predicted outsourcing relationship will be with preferred and trusted suppliers but in contrast to current practice, greater attention is likely to be given to performance-based contracts, strategic alliances, and partnership arrangements, some of which may involve joint risks, liabilities, and rewards. The present orientation of single contracts between purchasers and suppliers is predicted as unlikely to continue in the future as now. Outsourcing with multiple suppliers is viewed as likely to remain as that of today. A common theme to emerge between current and predicted future sourcing arrangements is the "ring fencing" of key relationships with trusted suppliers. Achieving such a high quality of relationship is reported as difficult to achieve, but once attained, con-

\section{Figure 3. Sourcing}

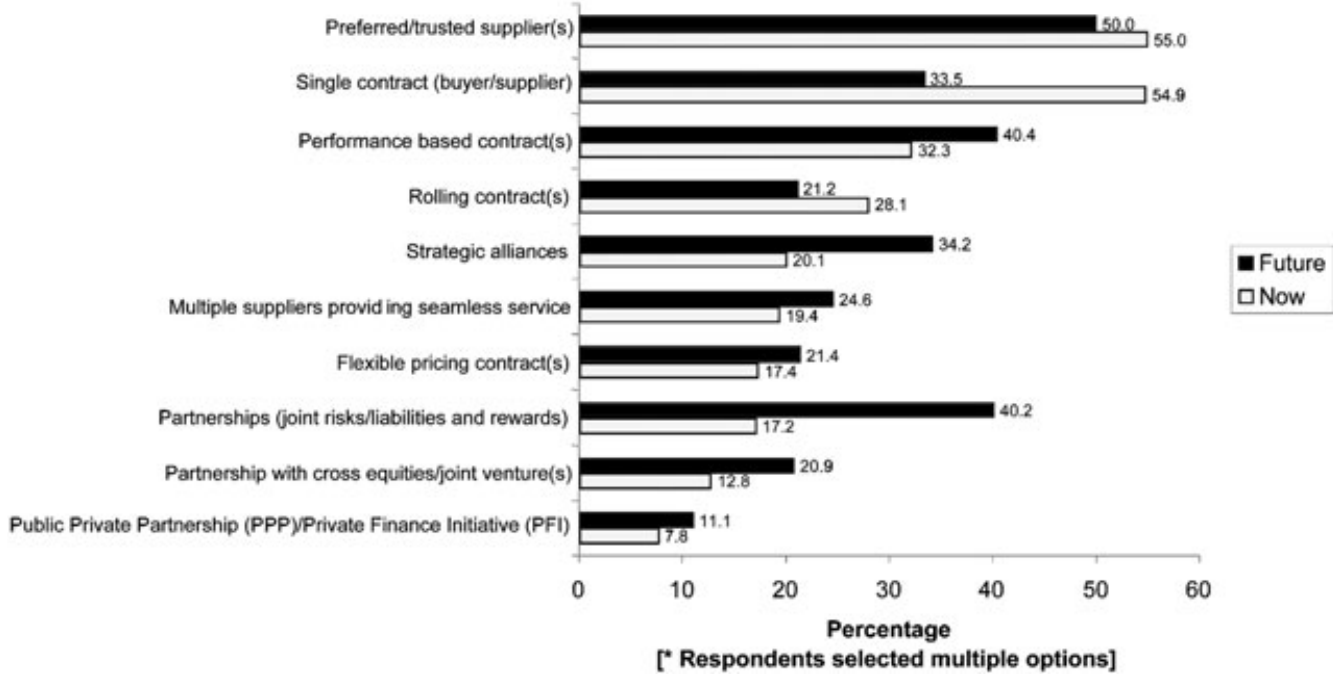

Adapted from Kakabadse and Kakabadse (2002a). 
tinuous attention and nurturing to maintain sound levels of interaction between the host organization and supplier(s) is considered necessary.

Thus, the shift from single contract to partnership and other risk-sharing arrangements will carry with it the need to develop requisite skills in outsourcing management combining "vertical" competencies and "lateral" competencies (Kakabadse \& Kakabadse, 1999; Larsson, Brousseau, Driver, Holmquist, \& Tarnovskaya, 2003). Vertical competencies, associated with efficiency requiring quantitative analysis for decision making, and the effective utilization of cost-control tools will need to be well blended with lateral competencies such as cooperation, alliance-building, partnering, teamwork, cultural diversity, creativity and the pursuit of corporate social responsibility (CSR).

Integrating contrasting ways of working has emerged as an important competence for successful current If a company chooses to utilize outsourcing as a lever for achieving competitive advantage, then it has to build core competencies around the skills of finding the right partners and the management of external relationships. They also have to have processes in place that can integrate a network of suppliers.

(General Manager, Energy Sector)

Integrating contrasting ways of working has emerged as an important competence for successful current and future sourcing practice. The first step is to recognize that change is needed and to motivate staff and management to adapt from the "way things are done" to more closely integrating with suppliers in order to achieve the objectives of the outsourcing exercise. As highlighted, the ability to manage relationships and the discipline to effectively apply total quality management (TQM) throughout the outsourcing process are crucial to the effective management of outsourcing arrangements. The study emphasizes that success is more likely to be achieved for those organizations that have the competence to:

- rearrange ways of working,

- integrate current processes and activities around activities already outsourced,

- facilitate ongoing relations,

- build long-lasting relationships with their suppliers, and

- effectively apply TQM.

\section{OUTSOURCING IMPACT ON EMPLOYEES}

Outsourcing is attractive to us because activities can be located into places that offer the most appealing economic conditions. 
However, this does not mean locating activity into the cheapest location with the cheapest service provider, but locating to the cheapest location with the best-qualified service provider that can support the necessary activity/function. Therefore, the decision as to what makes a service provider attractive within a particular location can include skill base, cultural and infrastructure considerations, and geo-political conditions. Being a very large enterprise, what ever we do has both positive and negative consequences on the local and global labor market.

(Vice President, Telecommunications Company)

The more commonly reported outsourcing arrangements currently for employees is the transfer of staff to suppliers (Figure 4). In support, a mixture of HR strategies is also adopted to suit the particular circumstances of the outsourcing contract. Senior managers further report that outsourcing has no detrimental effect on the management of people or on the contract terms employees have with their present employer or new employer. The survey results highlight that outsourcing minimally impacts the security of employment of staff, as redeployment with existing conditions is reported as the norm. Only a minority of companies report more basic changes to employment conditions, at times leading to redundancies. The least utilized arrangement for employees is redeployment with new terms and conditions of contract. The survey highlights that current practice is

\section{Figure 4. Outsourcing Impact on Employee}

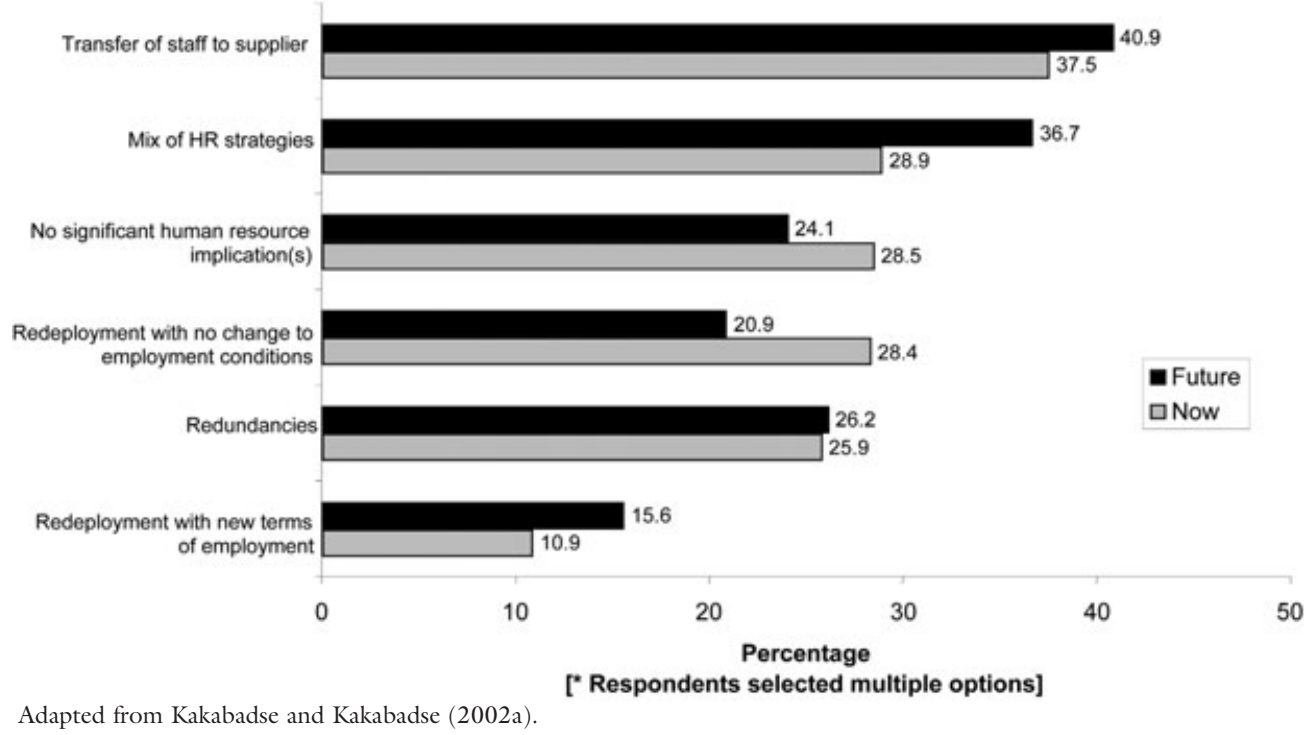


toward keeping people or redeploying them, but with little or no change to their arrangements of employment.

Concerning future arrangements for employees, the survey indicates that preference will be given to the two same strategies for addressing HR issues-namely, the transfer of staff to suppliers and the adoption of a mix of HR strategies. The difference is that these two strategies are likely to be applied with even greater vigor. It also seems that less effort is to be made to ensure that no adverse HR implications arise out of outsourcing. Redeployment is likely to continue, but with reduced emphasis on no change to employment conditions. Redundancies are predicted to remain at the same level as is currently the case. The predicted difference between current and future practice concerning $\mathrm{HR}$ arrangements resulting from outsourcing is that the redeployment of staff and management will probably involve some renegotiation of terms and conditions of employment.

A number of the interviewees indicated that these new arrangements often result in an undermining of the implicit contract between employees and the organization concerning security of tenure and loyalty, with new forms of employment arrangements emerging-namely, limited-term contracts, associate-relationship, and home-based teleworking. Study respondents also highlight that advances in information technology have also created new work options. For example, Internet, Web, and related e-business technologies are expected to marginalize dealers, distributors, and other commercial go-between middlemen by putting buyers and sellers of goods and services in direct contact, thus bypassing intermediaries and creating a "dis-intermediation" of the market. Respondents emphasize that these technologies have attracted a large number of new enterprises whose purpose is to "hook up" sellers and buyers, thus creating a new kind of middleman, the info-mediaries. Info-mediaries, together with aggregators, bubs, auction sites, portals, and exchanges, are labels used for those e-based companies whose aim is to improve market-clearing dynamics by leveraging the accessibility, efficiency, and information-richness of the Web (Kakabadse \& Kakabadse, 2002b).

The appeal of the modern-day middle-agent, the info-mediary, is based on the unique ability to exploit the Internet's three most salient characteristics, the shift of power from sellers to buyers through reducing the cost of switching suppliers, thus encouraging greater flexibility of distribution. As a result, many buyers feel liberated to make choices, while others feel overwhelmed by the amount of available information and choices. On this basis, many of the study 
participants emphasize that the role of chief purchasing officer is increasingly becoming more important.

\section{RECOMMENDATIONS}

...the advantages to be realized through outsourcing are of an operational and strategic nature.

\begin{abstract}
Anything that leverages outside resources to the good of your organization is a form of outsourcing. Do it-it helps your company!
\end{abstract}

(CEO, Information Services)

The overview of current and future sourcing practice indicates that the advantages to be realized through outsourcing are of an operational and strategic nature. Operational advantages usually provide for shortterm trouble avoidance, while strategic advantages offer long-term contribution in terms of maximizing opportunities. The study findings indicate that proactive organizations search for new ways of organizing their various elements of work in order to realize operational and strategic advantage. Thus, in order to achieve both sets of advantages, activities can be segregated against two considerations, gaining competitive advantage and quality, in order to identify which activities should be insourced against those that should be outsourced.

Competitive analysis classifies activities as competitive and noncompetitive, with those in the latter category acting as good candidates for outsourcing. Additional criteria need also to be applied, particularly the extent to which an activity is:

- responsive to change,

- requiring of further control, and

- exposed to considerable customer contact/interaction.

Through such analysis, activities that are deemed to fall into the competitive category need to be further assessed against the second criterion of quality. If there is a need to maintain or enhance superior quality, that activity may still be outsourced to a supplier who has accredited standards and TQM processes in place. However, if quality criteria are applied and the present sourcing of the activity remains competitive, then outsourcing may not be a viable option.

Competitive advantage through sourcing externally can be achieved on the basis that:

- outsourcing of noncompetitive and/or peripheral activities allows management to focus on the core competencies of their 
organization and establish a clear differentiation from their competitors, and

- achieving economies of scale allows the organization to gain from greater cost disciplines and the attainment of internal efficiencies.

\section{CONCLUSION}

\begin{abstract}
Organizations have traditionally carried out a wide range of extremely diverse and frequently noncore activities in-house. Changing markets, increasing deregulation, and intensified global competition are now forcing a fundamental reappraisal of organizational activities. This leads to an increasing shift back to core operations and activities and, in some cases, further shrinking of the value chain within the organization.
\end{abstract}

(General Manager, Financial Services) ...greater importance is likely to be attached to an existing trend of effectively managing relationships with key trusted suppliers.

The critical difference between current and future outsourcing trends and practice is that greater importance is likely to be attached to an existing trend of effectively managing relationships with key trusted suppliers. The marginally greater emphasis in the future is that each supplier in the chain is likely to be chosen and deployed to provide best-in-class service to the purchasing organization. Enabling the service purchaser to gain greater competitive advantage and assistance to move up the value chain is considered to require pursuing multiple outsourcing strategies, ranging from improving service quality while simultaneously striving to attain cost advantage. The survey participants consider that such goals are more likely to be realized through a variety of outsourcing arrangements, driven by performance-based contracts. For the best-run companies of the future, establishing meaningful contractual relationships with a number of key business partners in order to improve quality, while simultaneously applying great cost discipline is likely to become an ever-greater competitive imperative. The push to externalize and become an extended networked enterprise bears resemblance to the Japanese Keiretsu model (Helper \& Sako, 1995).

For a considerable time, Japanese automotive and high-technology enterprises have engaged in successful subcontracting based on a culture of intercompany cooperation (Kakabadse \& Kakabadse, 2000). The Keiretsu relationship has accounted for approximately half of the configurational structures of all Japanese enterprises (Cusumano \& Takeishi, 1991). The Keiretsu alliance is built on the principles of long-term partnerships, trust, information exchange, and limiting the 
impact of competitive pressure on suppliers (Aoki \& Dore, 1996). Traditionally, Japanese organizations have tended toward being vertically linked but integrated with suppliers, distributors, banks, and trading companies. In balancing vertical and horizontal configurational elements, Keiretsu-oriented enterprises have become accustomed to managing long-standing relationships involving equity holdings while equally enhancing each other's corporate reputation (Dyer \& Ouchi, 1993). Keiretsu-type relationships have been considered to enable greater focus and business discipline for the benefit of the partners by the partners (Thomas \& Waring, 1999). Suppliers are permitted to make the investments that will help them to accelerate through their learning curve of providing high-quality service, principally through having a lower cost-per-unit-based relationship with the parent organization (Chalos \& Sung, 1998). Such interwoven relationships have encouraged longer-term planning, greater investment, and the promotion of a culture of innovation (Quinn, 1999). Promoting innovative practice while pursuing economies of scale is a positive outcome of Keiretsu interlinkages (Quinn, 1999).

Irrespective of the economic downturn in Japan, the Cranfield survey indicates that in order to improve relationships with suppliers, particular operational and strategic capabilities will need to be applied in order to achieve high-quality outsourcing. In striving for best practice, adopting a "Keiretsu mind-set" of simultaneously pursuing relationships with best-in-class suppliers for the purposes of both greater innovation and enhanced management of costs is predicted as the norm for the future. The message is look to how the Japanese manage their corporate infrastructure, but not to how they manage their economy.

\section{REFERENCES}

Alexander, M., \& Young, D. (1996). Strategic outsourcing. Long Range Planning, 29(1), 116-119.

Aoki, M., \& Dore, R. (Eds.). (1996). The Japanese firm: The sources of competitive strength. Oxford, UK: Oxford University Press.

Bain, S. (2000, July 4). BoS outsources trustee services. The Herald, Glasgow, p. 18.

Barthelemy, J. (2001). Trends and emerging values in human resource management-The UK scene. International Journal of Manpower, 22(3), 261-268.

Blumenstein, R. (1997, May 16). GM puts onus for some costs on suppliers. Wall Street Journal, p. A3.

Carey, R. (1995). Consider the outsourcing. Incentive: Performance Supplement, No. 4, p. 4. Chalos, P., \& Sung, J. (1998). Outsourcing decision and managerial incentives. Decision Science, 29, 901-919.

Costa, C. (2001). Information technology outsourcing in Australia: a literature review. Information Management and Computer Security, 9(5), 1-14. 
Cunningham, S. (2001). Outsourcing: The key to adding value. International Tax Review, $12(6), 13-17$.

Currie, W., \& Willcocks, L. P. (1997, December). New strategies in IT outsourcing: Major trends and global best practice-Report. London: Business Intelligence Ltd.

Cusumano, M. A., \& Takeishi, A. (1991). Supplier relationships and management: A survey of Japanese transport and United States auto plants. Strategic Management Journal, 12, 563-588.

DiRomualdo, A., \& Gurbaxani, V. (1998). Strategic intent for IT outsourcing. Sloan Management Review, 39(4), 67-80.

Domberger, S. (1998). The contracting organization: A strategic guide to outsourcing. Oxford: Oxford University Press.

Duffy, M. N. (2001). Outsourcing a 401(K) plan. Journal of Accountancy, 191(5), 30-35.

Dyer, J. F., \& Ouchi, W. G. (1993). Japanese-style partnership: Giving companies a competitive edge. Sloan Management Review, 35, 51-63.

Finlay, P. N., \& King, R. M. (1999). IT outsourcing: A research framework. International Journal of Technology Management, 17(1-2), 109-128.

Foremski, T. (1999, August 9). Companies and finance: International: EDS wins Dollars 3.3bn contract. Financial Times (USA Edition), p. 17.

Forrester Research. (1999, April). Outsourcing's future-Report. Cambridge, UK: Author.

Gamble, R. H. (1995). Inside outsourcing. Corporate Cashflow, 16(8), p. 2-14.

Gartner Group. (1999, June 30). The changing external services market-Report. No. Findg19990630-01, Gartner IT Executive Program (gartner6.gartnerweb.com).

Grant, R. M. (1995). Contemporary strategy analysis. Cambridge, UK: Blackwell Business.

Gupta, A. (2000). Enterprise resource planning: The emerging organisational value systems. Industrial Management and Data Systems, 100(3), 114-118.

Halachmi, A., \& Montgomery, V. L. (2000). Best value accountability: Issues and observations. International Review of Administrative Sciences, 66(3), 387-414.

Heikkila, P. (2000, August 11). IBM scoops \$2000m outsourcing deal. Procurement, p. 1.

Helper, S. R., \& Sako, S. (1995). Supplier relationship in Japan and the United States: Are they converging? Sloan Management Review, 36(3), 77-84.

Hurley, M. (2001). IT outsourcing-Managing the key asset. Information Management and Computer Security, 9(5), pp. 1-7.

International Data Corporation (IDC). (2000). Top 100 worldwide outsourcing deals of 2000. Report No. B24482. Framingham, MA: Author.

Inkpen, A. C., \& Beamish, P. W. (1997). Knowledge, bargaining power, and the instability of international joint ventures. Academy of Management Review, 22(1), 177-202.

Insinga, B. B., \& Werle, M. J. (2000). Linking outsourcing to business strategy. Academy of Management Executive, 14(4), 58-70.

James, G. (2000, October 30). How companies court disaster in outsourcing deals. Computerworld, p. 1 .

Kakabadse, A., \& Kakabadse, N. (1999). Essence of leadership. London: Thomson International. Kakabadse, A. P., \& Kakabadse, N. (2000). Outsourcing: A paradigm shift. Journal of Management Development, 19(8) (Monograph), pp. 668-778.

Kakabadse, A. P., \& Kakabadse, N. (2002a). Smart sourcing: International best practise. New York: Palgrave.

Kakabadse, N., \& Kakabadse, A. (2002b). Application service providers (ASPs): New impetus for transformational change. Knowledge and Process Management, 9(4), 205-218.

Klein, P. (1999, November 15). Outsourcing's third wave. Information Week, pp. 126-127.

Koudsi, S. (2001, August 13). Sam's big blue challenge. Fortune, pp. 56-59.

Larsson, R., Brousseau, K. R., Driver, M. J., Holmquist, M., \& Tarnovskaya, V. (2003). International growth through co-operation: Brand-driven strategies, leadership and career development in Sweden. Academy Management Executive, 17(1), 7-24.

Lavelle, J. P., Krumwiede, D. W., \& Sheu, C. (2000). A privatisation model for government outsourcing. Production and Inventory Management Journal, 4l(2), 45-51.

Malek, J. (2000). R\&D outsourcing that works. Pharmaceutical Executive, 20(3), 70-78.

May, A. S. (1998). Business process outsourcing: A new test of management competence. Career Development International, 3(4), 84-91. 
McCure, A. (2001, May 24). IBM signs outsourcing deal with Fiat. Computing, p. 3.

Miles, R. E., \& Snow, C. G. (1997). Organizational strategy, structure and process. New York: McGraw-Hill.

Mishra, K. E., Spreitzer, G., \& Mishra, A. K. (1998). Preserving employee morale during downsizing. Sloan Management Review, 39(2), 83-95.

Mullin, R. (1996). Managing the outsourced enterprise. Journal of Business Strategy, 17(4), 28-32.

Murray, J. Y., \& Kotabe, M. (1999). Sourcing strategies of US service companies: A modified transaction-cost analysis. Strategic Management Journal, 20, 791-809.

Nairn, G. (1999, August 4). Companies can tap into a growing range of services. Financial Times, FT-IT Review 3, p. 3.

Nee, E. (1999). Webware for rent. Fortune, 140(5), 215-224.

Privatising war. (2003). Nexus New Times, 10(3), p. 6.

Peters, T., \& Waterman R. (1982). In search of excellence. New York: Harper and Row.

Prahalad, C., \& Hamel, G. (1990). The core competence of the corporation. Harvard Business Review, 68(3), 79-91.

Quinn, J. B. (1999). Strategic outsourcing: Leveraging knowledge capabilities. Sloan Management Review, 40(4), 9-22.

Quinn, J. B., \& Hilmer, F. G. (1994). Strategic outsourcing, Sloan Management Review, 35(4), 43-55.

Richbell, S. (2001). Trends and emerging values in human resource management-The UK scene. International Journal of Manpower, 22(3), 261-268.

Shelgren, D. (2000). HR outsourcing. Journal of Business Strategy, 22(4), 4-5.

Sparrow, P. R. (2000). New employee behaviours, work designs and forms of work organization. What is in store for the future of work? Journal of Managerial Psychology, 15(3), 202-218.

Standen, P., Daniels, K., \& Lamond, D. (1999). The home as a workplace: Work-family interaction and psychological well-being in telework. Journal of Occupational Health Psychology, 4(4), 368-381.

Teresko, J. (1999). ERO outsourcing. Industry Week, 248(16), 38-41.

Thomas, L. G., III, \& Waring, G. (1999). Competing capitalism: Capital investment in America, Germany and Japanese firms. Strategic Management Journal, 20, 729-748.

Tregaskis, O. (1999). Telework in its national context. In K. Daniels, D. Lamond, \& P. Standen (Eds.), Managing telework (pp. 97-115). London: ITP.

Tyson, W., \& York, A. (2000). Essentials of HRM (4th ed.). Oxford: Butterworth-Heinemann. van Laarhoven, P., Berglund, M., \& Peters, M. (2000). Third-party logistics in Europe-Five years later. International Journal of Physical Distribution and Logistics Management, 30(5), 425-442.

Willman, J. (1999, September 22). Unilever to focus on core "power brands." Financial Times, p. 25 . 